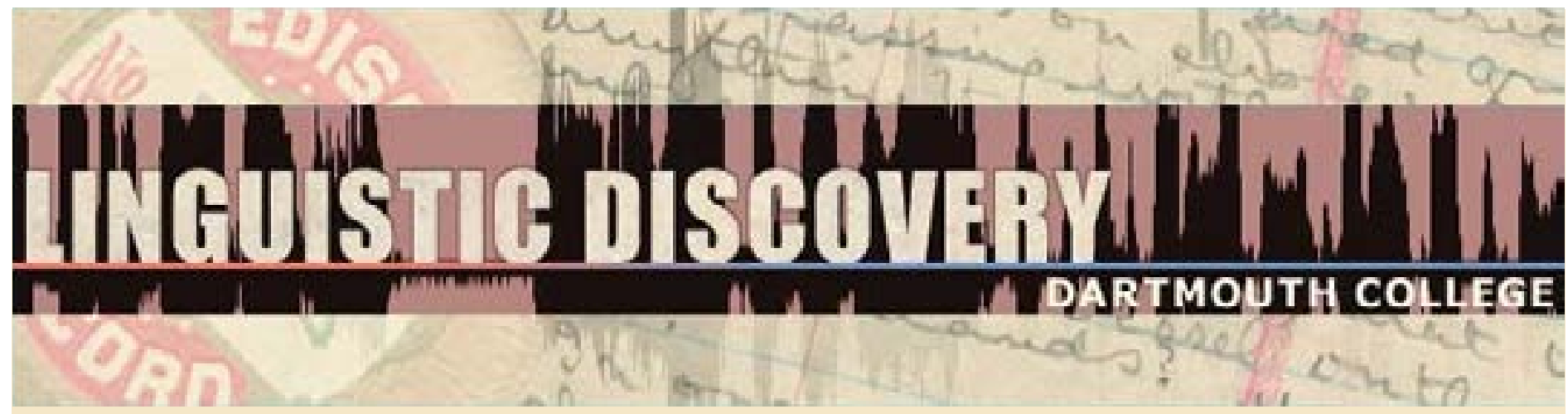

Volume 9

Issue 2 2011
The Expression of Evidentiality between Lexicon and Grammar. A Case Study from Georgian

Manana Topadze Gäumann

University of Bern

doi: $10.1349 / P S 1.1537-0852 . A .392$

url: http://journals.dartmouth.edu/cgi-bin/WebObjects/ Journals.woa/1/xmlpage/1/article/392
Linguistic Discovery

Published by the Dartmouth College Library Copyright to this article is held by the authors. ISSN 1537-0852 linguistic-discovery.dartmouth.edu 


\section{The Expression of Evidentiality between Lexicon and Grammar. A Case Study from Georgian ${ }^{1}$ \\ Manana Topadze Gäumann \\ University of Bern}

Evidentiality in Georgian is generally regarded as a part of the TAM-paradigm, since the perfect tense developed evidential value as a secondary meaning. The reference to the information source can also be expressed by other means such as quotative markers or semigrammaticalized lexical items. This paper gives a short overview of evidential structures in Georgian both at grammatical and lexical levels, analysing the current grammaticalization processes of evidentials in contemporary urban Georgian.

\section{Evidentiality-Theoretical Framework}

Evidentiality is a linguistic category with reference to the information source, on the basis of which the speaker makes a statement; this may be a direct or an indirect knowledge about an event acquired by inference, hearsay, assumption or perception. Evidentiality is morphologically realized only in a quarter of the languages of the world (Aikhenvald 2004:1), the remaining languages employ several other evidential strategies to convey the information source. Two large areas where evidentiality is encoded in the tense system mainly are the Balkans and the Caucasus (De Haan 2005b: 319). In most Germanic languages as well as in Finnish evidentials are expressed through modals, which acquire secondary meanings (De Haan 2005a: 315). The main source of evidentials is the grammaticalization of lexical categories, for example the grammaticalization of verbs of speech and perception verbs in quotative markers (Aikhenvald 2004). In some languages evidential meanings developed as secondary meanings out of tenses and moods of the verbal paradigm. These extensions are labelled by Aikhenvald "evidentiality strategies". She separates them strictly from the pure evidentials, whose primary meaning is information source (Aikhenvald 2004:105).

The terminology denoting evidentiality is not homogeneous in the linguistic literature; various terms have been adopted in different grammatical traditions. Aronson (1977) employed for Balkan Slavic the term 'status', indicating a verbal category characterized by the speaker's evaluation of the narrated event (Aronson 1977 apud Friedman 1979:339). Shanidze (1973) introduced for Georgian the semantic category of 'act' (Georgian akti) to make a distinction between unmarked (non evidential) and marked (evidential) narrative forms (cf. §2.1.) Evidentials are also labelled as 'mediatives' (Guentcheva 1996), 'confirmatives' (Aronson 1977), 'non-confirmatives' (Friedman 1979:339), 'validationals' or 'verificationals' (Aikhenvald 2004:15) etc.

Regarding the semantic distinction, evidentials are generally divided into direct and indirect evidentials (Givon 1982). Direct evidentials are used when the speaker has some sensory evidence for the action or event he is describing, whilst indirect evidentials are employed when the speaker reports an event which he did not witness but comes to know about it from an actual state. Indirect evidentials are split in two subcategories of inferential and quotative (also known as reportatives, reportive, reported, hearsay or second-hand) evidentials (cf. De Haan 2005a:314,

\footnotetext{
${ }^{1}$ The material presented in this article is a brief summary of a part of the $\mathrm{PhD}$ thesis completed by the author at the University of Pavia, Italy (Topadze 2008).
} 
Aikhenvald 2004:177). Aikhenvald (2004:23) proposes to distinguish evidential systems with two, three, four, five and more choices. Those with only two choices (firsthand vs. non-firsthand) she labels as "small" systems. They are widespread particularly in Eurasia (the Balkans, the Caucasus and the Finno-Ugric area). The distinction between firsthand vs. non-firsthand information is compatible with the subdivision of the Evidentiality domain into direct and indirect evidentiality, introduced by Willet (1988:57):

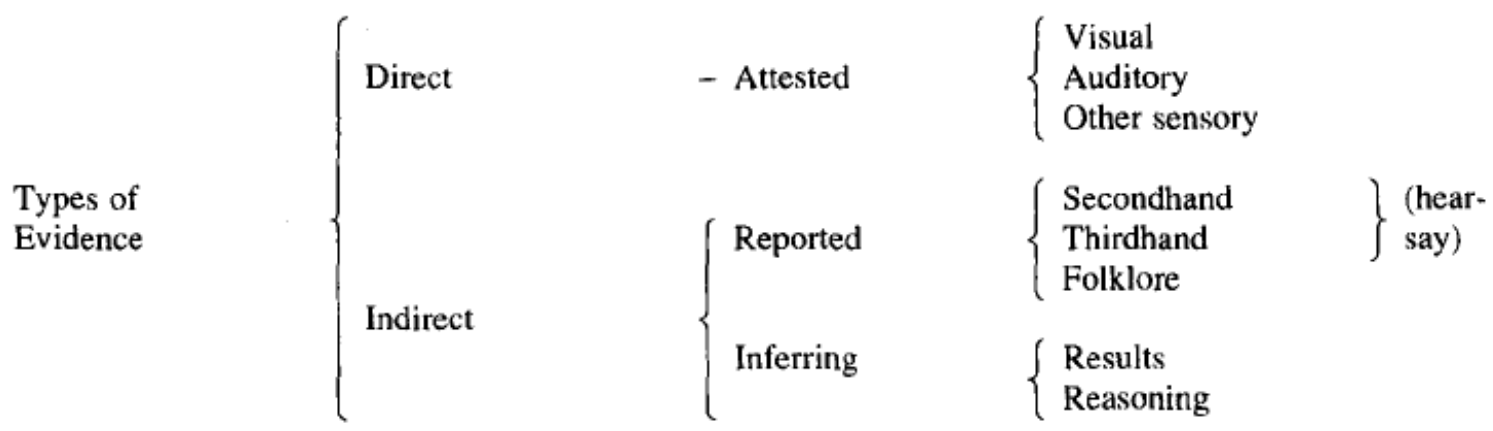

Figure 1: The semantic domain of evidentiality.

Evidentiality may acquire mirative (also known as admirative) extensions. Mirativity is frequently related to the emotional factor. It conveys the 'speaker's unprepared mind' (De Lancey 1997), it expresses the speaker's surprise at the moment of discovering unexpected information, which can be positive or negative. Indirect evidentials tend to acquire mirative overtones. However, mirative meanings do not always have to be expressed through evidentials (Aikhenvald 2004).

Aikhenvald makes a clear distinction between epistemic modality, which refers to the subjective evaluation of the speaker with regard to the reliability of the utterance expressed, and evidentiality which marks objectively the information source of the statement. The two notions may co-occur in the same forms or cluster in different ways. Thus, it is useful to keep the domains separate, both on conceptual and functional level.

\section{Evidentiality in Georgian}

\subsection{Previous studies}

In the Georgian grammatical tradition the concept of evidentiality was mentioned for the first time by Platon Ioseliani (1863), who observed that the expression of non-witnessed events, in his words 'events which the speaker has not seen with his own eyes' was possible by means of the particle /turme/ 'apparently, evidently'. Shanidze (1930: 124) pointed out that the meaning of /turme/ is encoded within the tense system of the Georgian verb (1930:123). To this regard Shanidze introduced later in 1953 the semantic category of "act": seen vs. unseen i.e. attended vs. non attended paying attention to the capacity of the Georgian verb to express witnessed and non-witnessed events (cf. Shanidze 1953:216, Shanidze 1980: 211): "Act or deed is a verbal form which shows us whether the speaker has seen the action expressed by the verb or not. The Georgian verb can denote not only actions witnessed and seen by the speaker, but also those which have not been witnessed and seen by the speaker. According to that, we have two acts, seen and unseen (i.e. attended and unattended)" (author's translation). Shanidze labelled the 
perfect and pluperfect tenses, which in contrast to the aorist (unmarked past form) developed evidential extensions as a secondary meaning, with "I turmeobiti" (I evidential i.e. perfect) and "II turmeobiti" (II evidential i.e. pluperfect). Furthermore Shanidze detected two possible meanings of the evidential perfect: reportive and inferential: "an unattended action can be recognized by the speaker in two ways: by hearing about it from someone else or by viewing the result of such an action and judging what could have happened" (Shanidze 1980: 211-212).

The morpho-syntactic features of the Georgian perfect have been widely investigated in a large number of linguistic studies, both in diachronic and synchronic perspective (see Chikobava 1950, Arabuli 1980, Harris 1981 and 1985, Natadze 1955, Pkhakadze 1984, Peikrishvili 1974, Shabashvili 2001 among others). In each of them evidentiality is considered one of the meaning of the perfect tense. A short history of evidentiality was drawn up by Kavtaradze (1956), who examined the occurrences of the particle /turme/ in Modern Georgian. He argued that the usage of /turme/ in expressing non-witnessed events is older than the occurrence of the perfect with evidential meaning. In his paper about the typology of 'status' in Georgian and other non-Slavic languages Friedman (1979) considered, along with the evidential perfect, the quotative particles as relevant lexical elements for the category of status (Friedman 1979:343). Furthermore he paid attention to the admirative value of the Georgian perfect, comparing it with admiratives in Balkan Slavic and Turkish. An important contribution has been offered by W. Boeder (2000) who drew up a detailed description of the evidential perfect, as well as evidential-like categories in Georgian.

\subsection{Types of evidentials ${ }^{2}$}

The evidentiality system in Georgian is subdivided into direct and indirect evidentials. According to Aikhenvald's terminology (Aikhenvald 2004: 24) this is a two term system ${ }^{3}$, which makes the distinction between firsthand and non-firsthand information.

Direct evidentiality is generally expressed through unmarked forms (cf. example 1). Non firsthand evidentiality is mainly encoded in the perfect (ex. 2) and sometimes in the pluperfect, since both tenses have evidential extension as a secondary meaning. For the non past tenses or in contexts where the use of the perfect is not possible, lexical means (quotative and evidential particles, adverbial expressions etc.) are employed for expressing the information source.

The inference can be conveyed by the future and the conditional as well. Both lexical and grammatical expressions of evidentiality have to be considered as evidential strategies rather than evidentials proper, since there is no overt morpheme conveying "information source" as its main meaning. Thus, Georgian has no specific grammatical marking for evidentiality, in the sense of Aikhenvald (2004), but a large number of grammatical and lexical strategies for its expression.

\footnotetext{
${ }^{2}$ The analysed data on Modern Georgian has been drawn from contemporary Georgian literature, magazines and newspapers. The TITUS database (University of Frankfurt) was exploited as the source for Old Georgian data. Data from the colloquial language was taken from different internet forums and collected by means of questionnaires and interviews.

${ }^{3}$ Term used by Aikhenvald (2004) who discusses evidential systems with two, three, four, five and more choices.
} 


\begin{tabular}{|l|l|l|l|l|}
\hline SERIES & SCREEVE $^{4}$ & TENSE & MOOD & ASPECT \\
\hline \multirow{4}{*}{ I Present } & Present & Present / Future & Indicative & \\
\cline { 2 - 4 } & Imperfect & Past & Indicative & \\
\cline { 2 - 4 } & Present subjunctive & Present / Future & Subjunctive & Imperfective \\
\cline { 2 - 4 } & Future & Future & Indicative & \\
\cline { 2 - 4 } & Conditional & Past & Indicative & \multirow{2}{*}{ Perfective } \\
\cline { 2 - 4 } & Future subjunctive & Future & Subjunctive & \\
\hline \multirow{4}{*}{ II Aorist } & Aorist & Past & Indicative & \multirow{3}{*}{ Perfective } \\
\cline { 2 - 4 } & Optative & Present / Future & Subjunctive & \\
& Perfect & Past & Indicative & \\
\cline { 2 - 4 } & Pluperfect & Past & Indicative & \\
\cline { 2 - 4 } & Perfect Subjunctive & Past/Future & Subjunctive & \\
\hline
\end{tabular}

Table 1: TAM paradigm of the Georgian Verb

\subsection{Grammatical strategies}

\subsection{The perfect}

The perfect tense in Georgian developed from the reanalysis of resultative constructions acquiring evidentiality as a secondary meaning. It expresses the unseen corresponding to the Series II (aorist) seen (Harris 1985):

seen: unseen:

Aorist Perfect

II series III series

$$
\begin{aligned}
& \text { man sk'am-i aivan-ze dadga. } \\
& \text { s/he:ERG chair-NOM balcony-on put:AOR.3SG } \\
& \text { 'S/he put the chair on the balcony'. }
\end{aligned}
$$

In contrast to (1), which expresses a witnessed event, the perfect form daudgams in (2a) conveys an unwitnessed event which can have an evidential (inferential, reportive or admirative) or in other contexts $(2 b)$ even a resultative or iterative meaning. Thus, the evidential value is one of the meaning of the perfect tense. For the non evidential uses of the perfect see Boeder (2000).
(2a) mas sk'am-i aivan-ze daudgams.
s/he:DAT chair-NOM balcony-on stand:PRF.3SG
'As it seems, s/he put the chair on the balcony'. (Inferential or reportive)

$\begin{array}{lllll}\text { mas } & \text { sk'am-i } & \text { aivan-ze } & \text { (xširad) } & \text { daudgams. } \\ \text { s/he:DAT } & \text { chair-NOM } & \text { balcony-on } & \text { (often) } & \text { stand:PRF.3SG } \\ \text { 'S/he has often put the chair on the balcony' } & \text { (Resultative, iterative). }\end{array}$

\footnotetext{
${ }^{4}$ Screeve is a paradigmatic set (tense-aspect-mood) of verbal forms which inflects only for person and number. The term screeve was coined by Aronson (1982), it is a phonetic adaptation of the Georgian term $m c$ ' $k$ 'rivi 'row', introduced by Shanidze in 1930.
} 
In example (2a) only the admirative value can be interpreted unambiguously, indicated by raising intonation in speech and by the exclamation mark in orthography. Inferential and reportive values as well as non-evidential meanings of the perfect can not be distinguished without the context. In (2b) the iterative meaning of the perfect is obvious, since it is reinforced by the temporal adverb / xširad/. If the information source must be marked in the same sentence, where the perfect has clearly non-evidential meaning, it must be done by lexical strategies of evidentiality, as in (2c):

$$
\begin{aligned}
& \text { mas sk'am-i } \quad \begin{array}{llll}
\text { aivan-ze } & \text { (xŠirad) } & \text { daudgams turme. } \\
\text { s/he:DAT chair-NOM } & \text { balcony-on } & \text { (often) } & \text { stand:PRF.3SG } \\
\text { EV }
\end{array} \\
& \text { 'Apparently /(as I was told), s/he has often put the chair on the balcony' } \\
& \text { (Iterative (perfect) + evidential (particle /turme/ 'apparently'). }
\end{aligned}
$$

The perfect can be found in contexts where it has a clearly resultative meaning, in particular with $1^{\text {st }}$ person subjects. The perfect is used as stylistic device in the literature and gives more expressivity to the language than the aorist (Peikrishvili 1974:58):

$$
\begin{array}{lllll}
\text { mečkareba, } & \text { saxl-i } & \text { bič'-is } & \text { amara } & \text { damit'ovebia. } \\
\text { hurry up:PRS:1SG } & \text { house-NOM } & \text { boy-GEN } & \text { with } & \text { leave:PRF.1SG }
\end{array}
$$

'I'm in a hurry, I left the servant alone in the house' (lit. 'I abandoned the house with the servant').

The necessity of avoiding ambiguity caused by the polysemy of the perfect brought about a creation of periphrastic constructions as an alternative to the resultative meaning, which contributed to the consolidation of evidential semantics of the perfect tense. The late $18^{\text {th }}-$ early $19^{\text {th }}$ centuries are considered to be the period of formation of such constructions (Sakhokia 2002).

In example (3) the interpretation of the perfect can be resultative or evidential, but the resultative meaning is minor, it is almost obscured by the evidential one. In (4) the perfect of (3) is replaced by the periphrastic construction (past participle of the main verb $+3^{\text {rd }}$ person present of the auxiliary), such a construction has only resultative meaning, the sentence is unambiguous.

$$
\begin{array}{lll}
\text { (mas) } & \text { c'ign-i } & \text { c'auk'itxavs. } \\
\text { He:DAT } & \text { book-NOM } & \text { read:PRF:3SG }
\end{array}
$$

'He apparently read the book'. / He read the book'. (Evidential or resultative).

$$
\begin{array}{llll}
\text { (mas) } & \text { c'ign-i } & \text { c'ak'itxuli } & \text { akvs. } \\
\text { he:DAT } & \text { book-NOM } & \text { read:P.P } & \text { have:PRS:3.SG }
\end{array}
$$

'He read the book' (Resultative).

The periphrastic constructions can express evidentiality when the auxiliary verb is used in the perfect screeve instead of present as in (5). In this case the only interpretation of the utterance is evidential. 


$\begin{array}{llll}\text { (mas) } & \text { c'ign-i } & \text { c'ak'itxuli } & \text { hkonia. } \\ \text { he:DAT } & \text { book-NOM } & \text { read:P.P } & \text { have: PRF:3.SG }\end{array}$

'He apparently read the book'.

The information source can also be marked by adding a lexical marker of evidentiality to the periphrastic construction as in (6).

$\begin{array}{lllll}\text { (mas) } & \text { c'ign-i } & \text { turme } & \text { c'ak'itxuli } & \text { akvs. } \\ \text { he:DAT } & \text { book-NOM } & \text { EV } & \text { read:P.P } & \text { have:PRS:3SG }\end{array}$

'He apparently read the book'.

For a detailed discussion about the uses of the evidential perfect see Boeder 2000, Giacalone and Topadze 2007, Topadze 2008.

Evidentiality in some contexts can also be expressed by pluperfect (inference or hearsay) conditional or future (only inference) screeves.

\subsection{The pluperfect}

The Pluperfect expresses an action anterior to another one which has also taken place in the past. The default value of the pluperfect is resultative. It can acquire an evidential extension (inferential or reportive) which can be reinforced by lexical markers:

$$
\begin{aligned}
& \text { sulganabul-i bulbul-i potl-eb-ši mimaluliq'o. } \\
& \text { silent-NOM nightingale-NOM leave-PL-in hide:PPRF:3SG }
\end{aligned}
$$

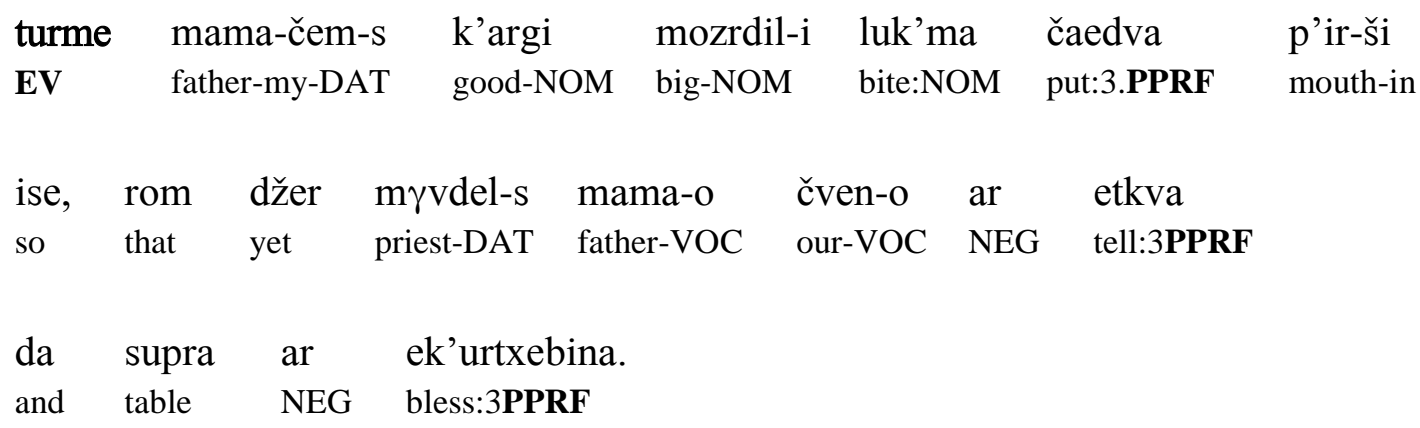

'Apparently my father had put in his mouth a big bite before the priest had said the "Lord's prayer" and had blessed the table'.

\subsection{The future}

Evidentiality encoded in the future overlaps with epistemic modality as in Romance and Germanic languages (cf. Pietrandrea 2005: 42). It expresses the inference based on internal (reasoning) or external (hearsay or common knowledge) source (cf. Giacalone and Topadze 2007). The inferential future takes on epistemic overtones of uncertainty (Boeder 2000:280), losing its temporal meaning: 


$$
\begin{array}{llllll}
\text { V-rek'av, } & \text { magram } & \text { aravin } & \text { p'asuxobs, } & \text { c'asul-eb-i } & \text { iknebian. } \\
\text { 1SUB-call:PRS } & \text { but } & \text { nobody } & \text { answer:PRS.3SUB } & \text { gone-PL-NOM } & \text { to be:FUT:3PL }
\end{array}
$$

'I am calling but nobody answers, they might be out'.

The number of verbs which can form the inferential future is quite restricted. These are usually stative verbs as codna 'to know', siq'varuli 'to love', kona 'to have', dždoma 'to sit', dgoma 'to stand', yireba 'to cost', c'ola 'to lie', etc.

\subsection{The conditional}

The conditional is equivalent to the future in the past. It substitutes the inferential future for the past events even for those verbs which do not admit inferential future forms:

$$
\begin{array}{lllll}
\text { ra } & \text { garudžul-i } & \mathrm{X} \text {-ar! } & \text { zyva-ze } & \text { iknebodi. } \\
\text { How } & \text { tanned-NOM } & \text { 2SUB-to be:PRS } & \text { sea-on } & \text { to be:FUT.2SUB }
\end{array}
$$

'How tanned you are! You must have been to the seaside'.

The conditional shares common traits with the perfect, since it refers to past events or their results, but, unlike the perfect, which is limited to stating a fact, the conditional conveys the speaker's commitment towards a statement.

\section{Lexical Strategies}

The reference to the information source can be expressed by employing lexical items, as mentioned above. They occur autonomously or in combination with grammatical strategies of evidentialty. They can modify the meaning of an utterance or intensify its evidential meaning. Quotative markers, comparative conjunctions, evidential particles, adverbial expressions as well as semigrammaticalized markers derived from verbs of perception can be considered lexical markers of evidentiality (an overview is given in table 2). In traditional grammars of Georgian lexical units with evidential value are usually mentioned along with the invariable words or modal particles (Shanidze 1980:612, Fähnrich 1986:146 among others). Among the markers of lexical evidentiality the quotative particles are undoubtedly the most discussed ones, especially in connection to indirect speech (Shanidze 1980, Hewitt 1981, Boeder 2000, 2002, Harris and Campbell 1995, Kvachadze 1996, etc.). The particle /turme/ 'apparently', lexical marker of evidentiality par excellence, is mentioned in numerous studies in correlation to the evidential meaning of the perfect tense (Shanidze 1980, Boeder 2000, Arabuli 1984, Pkhakadze 1984, Peikrishvili 1973, Fähnrich 1986, Hewitt 1995, among others) or to evidentiality more generally (Kavtaradze 1954, Boeder 2000). In the literature there are also some insights on inferential and reportive markers of evidentiality within investigations about conjunctions (Dzidziguri 1973) and mood (Jorbenadze 1982, Sharashenidze 1995, Harris 1995 etc.), discussing predominantly the epistemic-modal functions of these items. 


\begin{tabular}{|c|c|c|c|c|c|c|c|}
\hline $\begin{array}{c}\text { Types of } \\
\text { Evidentials }\end{array}$ & $\begin{array}{l}\text { Quotative } \\
\text { Markers }\end{array}$ & $\begin{array}{c}\text { Adverbial } \\
\text { Expressions }\end{array}$ & $\begin{array}{c}\text { Evidential } \\
\text { Particles }\end{array}$ & $\begin{array}{l}\text { Comparative } \\
\text { Conjunctions }\end{array}$ & $\begin{array}{c}\text { Semigrammatica } \\
\text {-lized Markers } \\
\text { derived from } \\
\text { perception verbs }\end{array}$ & Modals & $\begin{array}{l}\text { Degramma- } \\
\text { ticalized } \\
\text { Affixes }\end{array}$ \\
\hline Inferential & & & & & $\begin{array}{c}\text { et'q'oba } \\
\text { 'it seems' } \\
\text { čans } \\
\text { 'it is visible', } \\
\text { 'it seems' } \\
\text { mgoni } \\
\text { 'it appears, I } \\
\text { think' }\end{array}$ & $\begin{array}{l}\text { unda } \\
\text { 'must' }\end{array}$ & $\begin{array}{l}\text {-savit } \\
\text { 'it seems, } \\
\text { like, as' }\end{array}$ \\
\hline Reportive & $\begin{array}{c}\text {-metki } 1^{\text {st }} \\
\text { pers. sg } \\
\text {-tko } 2^{\text {nd }} \\
\text { pers sg/pl, } \\
1^{\text {st }} \text { pers. pl. } \\
\text {-o } 3^{\text {rd }} \text { pers. } \\
\text { Sg/Pl. }\end{array}$ & $\begin{array}{c}\text { mixedvit } \\
\text { tanaxmad } \\
\text { cnobit } \\
\text { gancxadebit } \\
\text { 'according to' }\end{array}$ & & & & & \\
\hline $\begin{array}{l}\text { Inferential/ } \\
\text { Reportive }\end{array}$ & & & $\begin{array}{c}\text { turme } \\
\text { 'apparently' }\end{array}$ & $\begin{array}{l}\text { titkos } \\
\text { 'as if' } \\
\text { vitom } \\
\text { 'as if' } \\
\end{array}$ & & & \\
\hline
\end{tabular}

Table 2: Lexical markers of evidentiality in Georgian

\subsection{Quotative markers}

In Georgian there are 3 quotative markers (also known as quotative particles or speech particles): [-metki], [-tko] and [-o]. The markers [-metki] and [-tko] are derived from the verb tkma 'to say'(-metki = me vtkvi, 'I said'. tko<tkva 'he said'). The origin of the particle [-o], which is used mainly for quotations in the third person, is obscure. The quotative markers can generally be cliticized to each constituent of the sentence. Usually they are used as direct speech markers.

The particle [-metki] is used to codify firsthand information. In the first person quotations the speaker uses [-metki] to report a statement made or thought by himself in the past. In this case [metki] serves as a marker of direct evidentiality i.e. firsthand information, since the speaker is personally the information source for the stated utterance. The particle [-metki] generally takes a final position within a sentence:

damagviandeba-metki.

to be late:1OBJ:FUT-1QUOT

'I will be late (I said)'.

In some dialects of Georgian [-metki] occurs as an autonomous lexical unit /metki/ in the headposition preceding the main verb (Dzidziguri 1973:446, Boeder 2002:17, 41 note 34). The original meaning of 'saying' is conserved:

$$
\begin{array}{lll}
\text { metki gaetrie } & \text { akedan! } \\
\text { 1.QUOT go away:2IMP } & \text { here:from } \\
\text { '(I said) Out of the way'! }
\end{array}
$$


The occurrence of /metki/ as an autonomous unit emerges also in contemporary urban Georgian, where it undergoes morphosyntactic and semantic changes, losing its original meaning of saying and acquiring epistemic overtones of surprise by discovering the opposite information from that expected by the speaker. Such use of /metki/ has not been previously discussed in the literature.

$\begin{array}{lllll}\text { kidev } & \text { ak } & \text { xar? } & \text { metki } & \text { c'axvedi! } \\ \text { Still } & \text { here } & \text { be:PRS:2SUB } & \text { EV } & \text { go away:AOR:2SUB }\end{array}$

'Are you still here? I thought you went away'.

In colloquial language /metki/ sometimes occurs twice in a sentence as an autonomous lexical unit (at the beginning) and as an enclitic (at the end of the sentence) in order to intensify the marking of reported speech:

$$
\begin{aligned}
& \text { metki c'amoiq'vane egec-metki. } \\
& \text { 1.QUOT to take with-2IMP he-too-1.QUOT } \\
& \text { (I said) Take him also with you (I said). }
\end{aligned}
$$

In contrast to [-metki] the quotative markers of the 2nd and 3rd person codify the second hand information. [-tko] is used when the addressee is a mediator between the speaker and a third person. The utterance is addressed to the third person, the information source is the speaker (see also Boeder 2002:15, Giacalone and Topadze 2007):

$$
\begin{array}{lllll}
\text { utxari, } & \text { d } \gamma \text { es } & \text { čem-i } & \text { st'umar-i } & \text { xar-tko. } \\
\text { tell:2IMP } & \text { today } & \text { my-NOM } & \text { guest:NOM } & \text { to be:2SUB-2QUOT }
\end{array}
$$

Tell him/her, you are my guest today ( $\mathrm{s} / \mathrm{he}=$ speaker, $1^{\text {st }}$ person said).

The quotative marker [-o] also reports second hand information. In contrast to [-metki] and [-tko] it does not necessarily specify the information source which can be common knowledge for others. The particle [-o] occurs often in proverbs. For a detailed discussion about quotative markers see (Shanidze 1980, Hewitt 1981, Boeder 2000, 2002, Harris and Campbell 1995, Kvachadze 1996, Giacalone and Topadze 2007).

In formal register the information source is generally marked by adverbial expressions (in the adverbial or instrumental case), such as: mixedvit (from xedva 'vision') 'according to' (lit. with the vision), tanaxmad (from xma 'voice') 'according to' (lit. with the voice), cnobit (from cnoba 'notice') 'according to the notice', gancxadebit (gancxadeba 'declaration') 'according to the declaration', inpormaciit (inpormacia 'information') 'according to the information', etc.

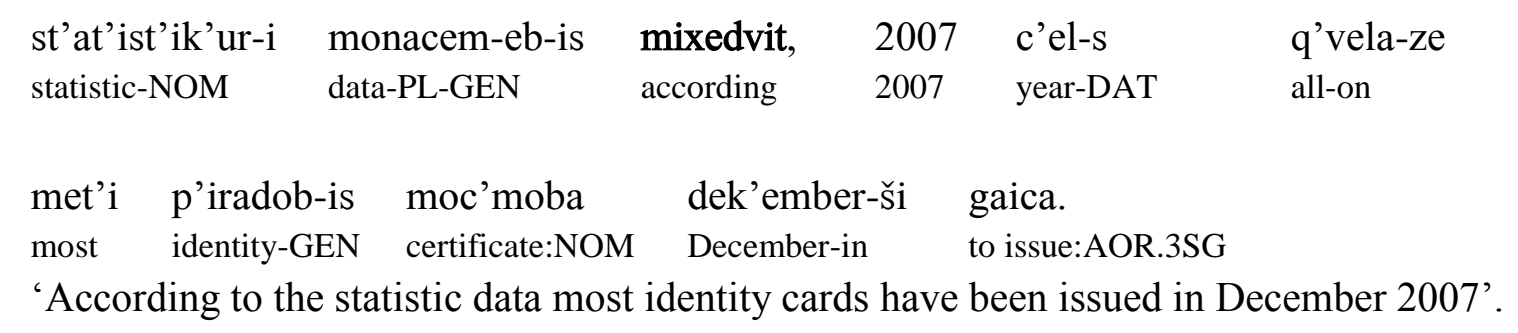




$\begin{array}{lllll}\begin{array}{l}\text { arsebul-i } \\ \text { available-NOM }\end{array} & \begin{array}{l}\text { inpormaci-is } \\ \text { information-GEN }\end{array} & \begin{array}{l}\text { tanaxmad, } \\ \text { according }\end{array} & \begin{array}{l}\text { samxareo } \\ \text { regional }\end{array} & \begin{array}{l}\text { p'olicia-m } \\ \text { policy-ERG }\end{array} \\ \text { uk've } & \begin{array}{l}\text { aydzra } \\ \text { already }\end{array} & \begin{array}{l}\text { gamodzieba. } \\ \text { to open:AOR.3SG }\end{array} & & \\ \text { inquiry:NOM } & & \end{array}$

'According to the available information, the regional police has already opened the inquiry'.

$\begin{array}{llllll}\begin{array}{l}\text { sinop't'ik'os-eb-is } \\ \text { meteorologist-PL-GEN }\end{array} & \begin{array}{l}\text { cnob-it } \\ \text { information-INS }\end{array} & \begin{array}{l}\text { xval } \\ \text { tomorrow }\end{array} & \begin{array}{l}\text { mtel } \\ \text { whole }\end{array} & \begin{array}{l}\text { sakartvelo-ši } \\ \text { Georgia-in }\end{array} & \begin{array}{l}\text { gamoidarebs. } \\ \text { to brighten } \\ \text { up:3FUT }\end{array}\end{array}$

'According to the meteorologists, tomorrow the weather will brighten up in the whole Georgia'.

\subsection{Evidential particles}

\subsection{Turme}

The invariable particle /turme/ 'apparently, seemingly, as it is said' grammaticalized from the union of the conjunction /tu/ 'if', the particle /re/ 'somewhat' and the indefinite particle /me/ (cf. Boeder 2000:281, 313). It does not reflect directly the meaning of the contained elements (Kavtaradze 1956:180). We find the first occurrences of /ture/ (earlier form of /turme/), in texts from the $12^{\text {th }}$ century (Arabuli 1984:142). In modern Georgian /turme/ has the same use as in Old Georgian. It may co-occur with the evidential perfect, but not obligatorily. The Georgian name of evidential screeves (turmeobitis mc'k'rivebi is derived from the particle /turme/.

/turme/ has both inferential and reportive value. It indicates that the speaker does not have direct knowledge of what he is retelling, it normally does not contain epistemic assessments and does not cast doubt on the reliability of the utterance. The combination [aorist of the main verb + /turme/] can replace the evidential perfect in all declarative phrases of indicative mood:

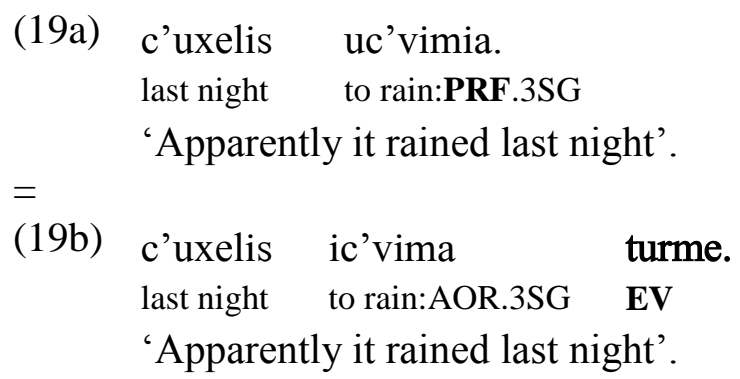

The particle /turme/ has its counterparts in all Kartvelian languages. In Megrelian it has been borrowed from Georgian, it is attested under the forms of /trume/, /turme/, /rtume/, whereas its Laz counterpart /megerem/ is a Turkic loanword. In Svan there is an autochthonous form equivalent of /turme/ attested under the form /esnar/ and its phonetic variants /ecnär//esnärildäš/, /esren/, /esreniš/) 'apparently'. The particle /turme/ and its counterparts in Kartvelian Languages can be combined with all (evidential and non evidential) screeves of the indicative mood. 


\subsection{Mgoni}

/mgoni/ 'it seems, it appears, seemingly, I think' (from $m$-gon-i- $a, 1^{\text {st }}$ person singular of the verb /goneba/ 'to think, to appear, to believe') works as a parenthetical element which modifies the meaning of the utterance, it contains a strong epistemic component of the speaker's commitment. /mgoni/ assumes evidential overtones in cases where it indicates the information source which serves as a basis of the statement.

Epistemic use (information source is not known):

$\begin{array}{llll}\text { ramden-i } & \text { c'l-isa-a? } & \text { mgoni } & \text { xut-is. } \\ \text { how many-NOM } & \text { year-GEN-to be:PRS:3SG } & \text { INF } & \text { five-GEN }\end{array}$

'How old is s/he? Five, as I believe' (speaker's memory).

Evidential use (information source is indicated):

$\begin{array}{llll}\text { narčit'as } & \text { čit'bat'onasac } & \text { edzaxian } & \text { mgoni. } \\ \text { kinglet:DAT } & \text { goldfinch:DAT:too } & \text { call:3SUB:PRS } & \text { INF } \\ \text { 'The kinglet is also called goldfinch, as it seems/I think (Hearsay). }\end{array}$

\subsection{Et'q'oba}

/et'q'oba/ 'noticeably', 'seemingly', grammaticalized as inferential marker from the 3rd person of the verb /šet'q'oba/ 'to notice'/dat'q'oba/ 'to be noticeable' (lit. 'It is noticeable on him/her'). It contains an epistemic element showing the speaker's attitude towards the statement. The use of let'q'oba/ is characteristic for the colloquial language. It also appears in less formal registers of the written language.

t'elepon-i gamoirto,
phone-NOM to switch off:AOR:3SG:PASS INF $\begin{aligned} & \text { element'-i daudžda. } \\ & \text { 'The phone got switched off. Apparently its battery got discharged'. }\end{aligned}$

With past events /et'q'oba/ occurs sometimes in the imperfect screeve. For this reason it must be considered as a semi-grammaticalized element, since it is not completely fossilized and is collocated on the continuum between lexicon and grammar (Topadze 2008):

$\begin{array}{llllll}\begin{array}{l}\text { Zvav-ze } \\ \text { landslide-on }\end{array} & \begin{array}{l}\text { džixv-eb-is } \\ \text { ibex-PL-GEN }\end{array} & \begin{array}{l}\text { naval-i } \\ \text { track-NOM }\end{array} & \begin{array}{l}\text { mravlad } \\ \text { much:ADV }\end{array} & \begin{array}{l}\text { iq'o. } \\ \text { to be:AOR.3.SG }\end{array} & \\ \begin{array}{lllll}\text { et'q'oboda } \\ \text { INF }\end{array} & \begin{array}{l}\text { c'q'l-is } \\ \text { water-GEN }\end{array} & \begin{array}{l}\text { dasalevad } \\ \text { for drinking }\end{array} & \begin{array}{l}\text { ak } \\ \text { here }\end{array} & \begin{array}{l}\text { evlo-t } \\ \text { go:PPRF-3PL }\end{array} & \begin{array}{l}\text { zevi-dan. } \\ \text { up-from }\end{array}\end{array}$

'There were many tracks of ibexes (mountain goats) on the landslide. Apparently (lit. as it seemed) they came down here to drink'. 


\section{6 Čans}

/čans/ 'it is visible' is another semi-grammaticalized inferential marker derived from the 3rd person singular of the verb /gamočena/ 'to appear', which loses its original function of marking direct evidence and assumes an inferential value. /čans/can co-occur with the evidential perfect:

\begin{tabular}{|c|c|c|}
\hline $\begin{array}{ll}\text { es } & \text { p'rozauli } \\
\text { this } & \text { prose:ADJ }\end{array}$ & $\begin{array}{l}\text { variant'-i, } \\
\text { version-NOM }\end{array}$ & $\begin{array}{l}\text { čans, } \\
\text { INF }\end{array}$ \\
\hline
\end{tabular}

'This prose version, as it appears, was versified by some Meskhi (=inhabitant of Meskheti, Georgian region)'.

Like /et'q'oba/, the marker /čans/ can occur also in the imperfect under the form /čanda/ 'it was visible') when it refers to past events:

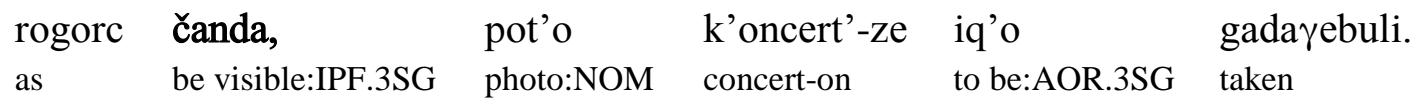

'As it seemed/ as it was visible, the photo was taken during the concert'.

\section{Inferential and Reportive Markers Derived from Conjunctions}

/titkos/ and $/$ vitom ${ }^{5}$ 'as if, as though' are evidential markers grammaticalized from the homonymous comparative conjunctions. In many contexts they may be used synonymously. /titkos/ (derived from /tu/ 'if' + optative of the verb /tkma/ 'to say') developed in modern Georgian an evidential (inferential and reportive) function with the meaning 'as it seems, as it is said'.

/vitom/ 'as if', 'as though' (derived from the Old Georgian comparative conjunction /vit(a)/ 'as' (cf. vit(a) >vitamca>vitomc $>$ vitom), developed a reportive value. In some context of illusory perception (such as dreams, etc...) it can have an inferential interpretation. Both /titkos/ and /vitom/ contain epistemic overtones. In comparative constructions the evaluation of the statement by the speaker expressed through /titkos/ can be positive or negative, whereas /vitom/ implies necessarily a negative attitude of the speaker towards an utterance.

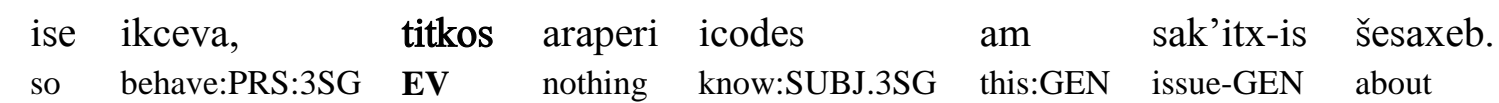

'He behaves as if he knew nothing about this issue'.

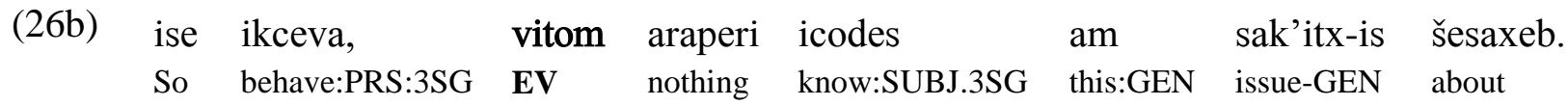
'He behaves as if he knew nothing about this issue' (Negative attitude of speaker)'.

\footnotetext{
${ }^{5}$ The conjunctions titkos and vitom have following phonetic variants: titkos: titkosda; vitom: vitomc, vitomda, vitomdac, vitomcda.
} 
/titkos/ and /vitom/ with evidential value occur often as parentheticals, losing in such cases the original function of connectors or conjunctions.

$\begin{array}{lllll}\text { mariam-i } & \text { titkos } & \text { gušin } & \text { dabrund-a } & \text { mtidan. } \\ \text { Mary-NOM } & \text { EV } & \text { yesterday } & \text { return:AOR-3SUB } & \text { mountain:from }\end{array}$

'Mary seems to have returned yesterday from the mountains'(Inferential or reportive)'.

/vitom/ is often accompanied by the hearsay marker $[-\mathrm{o}]$ :

$\begin{array}{lllll}\text { mariam-i } & \text { vitom } & \text { gušin } & \text { dabrund-a } & \text { mtidan-o. } \\ \text { Mary-NOM } & \text { EV } & \text { yesterday } & \text { return:AOR-3SUB } & \text { mountain:from:QUOT }\end{array}$

'Mary seems to have returned yesterday from the mountains, as they said' (Only reportive).

By using the marker /titkos/ the speaker does not assume any responsibility for the validity of the statements and reserves the possibility to change or withdraw his opinion or statement:

$$
\begin{aligned}
& \text { gšia? } \quad \text { titkos ara. } \\
& \text { Be hungry:PRS.2SG INF no } \\
& \text { 'Are you hungry? Seemingly not' (as I feel)'. }
\end{aligned}
$$

/vitom/ can be additionally used independently as a modal-interrogative particle, as in (29). In such a context it can not be replaced by /titkos/ (Topadze 2008):

$$
\begin{array}{lllll}
\text { - am } & \text { problem-is } & \text { gadač'ra } & \text { advilad } & \begin{array}{l}
\text { šeidzleba. } \\
\text { this:GEN }
\end{array} \\
\text { problem-GEN } & \text { solve-MASD } & \text { easily } & \text { be possible:PRS:3SG }
\end{array}
$$

This problem is easily solvable.

-vitom?

EV

'Can it be really true? Is it credible' (Scepticism of the speaker).

The derivation of evidential markers from comparative constructions is a typologically widespread phenomenon. (Wiemer 2008a:20, Wiemer 2008:348). Wiemer observes for Slavic languages that evidential elements developed from comparative constructions are inclined to oscillations between inferential and reportive domains. This claim seems to be valid also for the Georgian evidentials /titkos/ and /vitom/ which can be defined as 'undifferentiated indicators of indirect evidentiality, the designation proposed by Wiemer (Wiemer 2008:348).

\subsection{Inferential markers derived from modals. The case of unda}

The invariable marker /unda/ (3rd person of the verb /ndoma/ 'to wish, desire') developed as a marker of deontic modality, which in combination with the optative of the main verb can acquire an inferential value: 


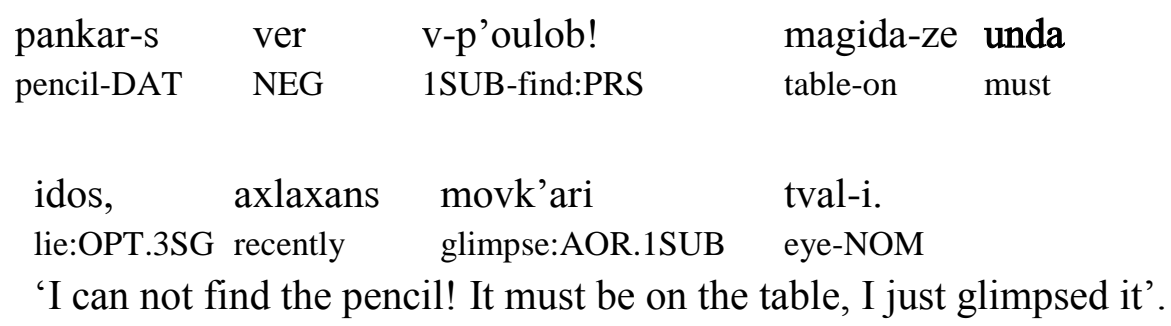

\subsection{Inferential markers derived from a nominal affix: -savit}

The suffix [-savit] is a clitic composed from the dative marker [-s] + epenthetic vowel [a-] and postposition [-vit] 'like', 'as' (Amiridze 2006). Its primary function is comparative:

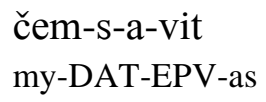

The clitic [-savit] grammaticalized as evidential suffix which can be cliticized to the finite verbal forms (Jorbenadze, Kobaidze, Beridze 1988:170, Amiridze 2006). In contemporary urban Georgian some forms can be found, where [-savit] functionally corresponds to the marker /titkos/ 'it seems, it appears' in its inferential uses:

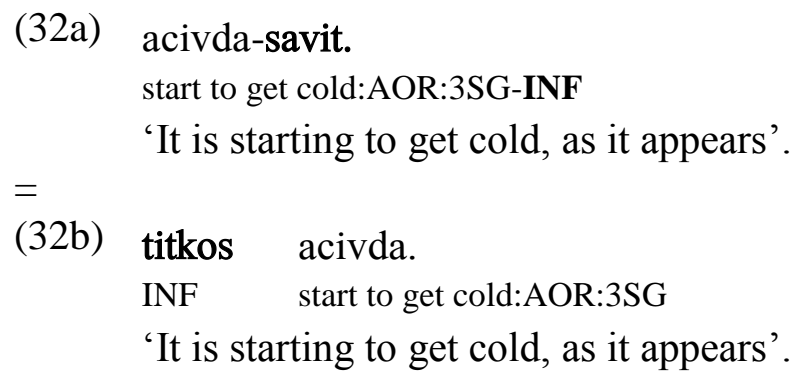

\section{Conclusions}

Summarizing results of the present discussion we can conclude that evidentiality in Georgian is a functional, semantic category. Marking the information source is not obligatory and it depends on the choices of the speaker. Evidentiality can be expressed by various grammatical and lexical means: direct evidentiality is codified by unmarked forms of TAM and by the first person quotative marker [-metki], whereas indirect evidentiality and its sub-domains of inference and hearsay are encoded in the TAM-paradigms, which have developed evidentiality as a secondary meaning, or can be conveyed by lexical means. There are no overt morphological i.e. verbal markers of evidentiality, with only the meaning of "information source".

As reflected by the analyzed data, the encoding of evidentiality in Georgian is not restricted to the indirect evidentiality, as sometimes claimed in the literature. The claim according to which Georgian marks only indirect evidentiality (second hand information) is valid for some grammatical strategies (e.g. the perfect), but not for all the means of expression of evidentiality.

In contrast to the grammatical strategies which developed evidentiality as a secondary meaning, like the perfect, some lexical strategies may have evidentiality as unique meaning. 
The investigated data confirm that evidentiality in Georgian is a domain in movement, which admits several intermediate stages, as manifested by the presence of both grammaticalization processes involving lexical items, and degrammaticalization processes involving affixes.

The evidential value may overlap with the epistemic one within a marker, as demonstrated by a large number of lexical means. However, such overlap is not obligatory, as for instance in the case of the perfect, which is not compatible with the epistemic elements. The Georgian perfect, which has developed an evidential value in addition to other meanings, corroborates the claim made by some authors (Aikhenvald 2004, De Haan 1999, Wiemer 2010) according to which evidentiality and epistemicity are two different notions, both at the conceptual and functional level.

\section{Abbreviations}

ADV-Adverb, ADJ-Adjective, AOR-Aorist, DAT-Dative, EPV-epenthetic vowel, ERGErgative, EV-Evidential, FUT-Future, GEN-Genitive, IMP-Imperative, INF-Inferential, INSInstrumental, IPF-Imperfect, MASD-Masdar, NEG-Negation, NOM-Nominative, OBJ-Object, PASS-Passive, PL-Plural, P.P-Perfect Participle, PPRF-Pluperfect, PRF-Perfect, PRS-Present, QUOT-Quotative, SG-Singular, SUB-Subject, TAM-Tense/Aspect/Mood, VOC-Vocative.

\section{References}

Aikhenvald, Alexandra Y. 2004. Evidentiality. Oxford: Oxford University Press.

Amiridze, Nino. 2006. Originally Nominal Affixation on Finite Verb Forms in Modern Georgian and Laz. Presentation at the International Workshop on Morphosyntax of Caucasian Languages. INALCO and Collège de France, Paris (Manuscript).

Arabuli, Avtandil. 1980. Mesame seriis nak'vteulta c'armoeba da mnišvneloba dzvel kartulši [The formation and meaning of the third series of tenses in Old Georgian]. Tbilisi.

Aronson, Howard I. 1977. The Interrelationships between Aspect and Mood in Bulgarian. Folia Slavica 1, 1.9-32.

-----. 1982. Georgian: A Reading Grammar. Columbus: Slavica Publishers.

Boeder, Winfried. 2000. Evidentiality in Georgian. In: Evidentials: Turkic, Iranian and Neighbouring Languages, ed. by Lars Johanson \& Bo Utas, Berlin-New York, Mouton de Gruyter, 275-328.

-----. 2002. Speech and thought representation in the Kartvelian (South Caucasian) Languages. In: Reported discourse: a meeting ground for different linguistic domains (Typological Studies in Language 52), ed. by. Tom Güldemann \& Manfred von Roncador. Amsterdam: John Benjamins, 3-48.

Chikobava, Arnold. 1950. Kartuli enis zogadi daxasiateba [A general characteristisation of the Georgian Language]. Kartuli enis ganmart'ebiti leksik'oni, ed. by A. Chikobava, Tbilisi.

De Haan, Ferdinand. 1999. "Evidentiality and epistemic modality: Setting boundaries", Southwest Journal of Linguistics, 18, 83-101.

-----. 2005a. Semantic Distinctions of Evidentiality. In: The World Atlas of Language Structures-WALS, ed. by Martin Haspelmath, Matthew S. Dryer, David Gil, Bernard. Comrie. Oxford: Oxford University Press, 314-317. 
-----. 2005b. Coding of Evidentiality. In: The World Atlas of Language Structures-WALS, ed. by Martin Haspelmath, Matthew S. Dryer, David Gil, Bernard. Comrie. Oxford: Oxford University Press, 318-321.

De Lancey, Scott. 1997. Mirativity: The Grammatical Marking of Unexpected Information. Linguistic Typology 1, 33-52.

Dzidziguri, Shota. 1973. K'avširebi kartul enaši ('Conjunctions in Georgian'). Tbilisi.

Fähnrich, Heinz. 1986. Kurze Grammatik der georgischen Sprache. Leipzig, Verlag Enzyklopädie.

Friedman, Victor. 1979. Toward a typology of status: Georgian and other non-Slavic languages of the Soviet Union. In: The elements: A parasession on linguistic units and levels, ed. by Paul R. Clyne, William Hanks \& Carol Hofbauer. Chicago Linguistic Society, 339-350.

Giacalone Ramat Anna \& Manana Topadze. 2007. The coding of evidentiality: a comparative look at Georgian and Italian. In: Evidentiality between lexicon and grammar, Italian Journal of Linguistics, n. 19,1, ed. by Mario Squartini, Pisa.

Givon, Talmy. 1982. Evidentiality and epistemic spaces. Studies in Language, 6, 23-49.

Guentcheva, Zlatka. 1996. L’Énonciation médiatisée. Bibliothèque de l'information grammaticale. Louvain: Éditions Peeters.

Harris, Alice C. 1981. Georgian Syntax. A study in relational grammar. Cambridge Studies in Linguistics, vol. 33. Cambridge, Cambridge University Press.

-----. 1985. Diachronic Syntax: The Kartvelian Case. Syntax and Semantics, vol. 18. Academic Press, Orlando.

-----. 1995. "Modal Auxiliaries in Georgian". In: Pilologiuri Dziebani (Festschrift for Guram Kartozia, ed. Aleksandre Gvakharia), Tbilisi, Mecniereba, 195-207.

Harris Alice and Lyle Campbell. 1995. Historical Syntax in Cross-Linguistic Perspective. Cambridge Studies in Linguistics, vol. 74. Cambridge University Press, Cambridge.

Hewitt, George B. 1981. "Eine weitere Betrachtung der georgischen Redepartikel '-tko//-tkva'. Georgica, $n .4$.

Ioseliani, Platon. 1863. P'iruel-dac'q'ebitni k'anonni kartulisa rrammat'ik'isa / šedgenilni p'lat'on egnat'es dzis ioselianisagan - aybeč'dilni mesamed [First Canons of Georgian Grammar, gathered by Platon E. Ioseliani, printed for the third time], Tbilisi.

Jorbenadze, Besarion. 1982. Nazmnari modaluri element'ebi kartulši. [Deverbal modal elements in Georgian], Kartuli sit'q'vis k'ult'uris sak'itxebi, 10. Tbilisi.

Jorbenadze Besarion, Manana Kobaidze \& Marine Beridze. 1988. Kartuli enis morpemebisa da modaluri element'ebis leksik'oni [Dictionary of Morphemes and Modal Elements of Georgian]. Tbilisi, Mecniereba.

Kavtaradze, Ivane. 1956. Unaxaobis k'at'egoriis ist'oriisatvis kartulši [On the History of the Category of Non-witnessedness in Georgian]. In: IKE (Iberiul-k'avk'asiuri enatmecniereba), 8, 179-193.

Kvachadze, Leo. 1996. Kartuli enis sint'aksi (Syntax of Georgian language). Tbilisi.

Natadze, Nodar. 1955. Mesame seriis dro-k'ilota c'armoebisatvis kartulši [On the formation on series III in Georgian]. In: IKE (iberiul-k'avk'asiuri enatmecniereba) 7, 81-98.

Peikrishvili, Zhuzhuna. 1974. Turmeobitebis mnišvneloba da gamoq'eneba axal kartulši [The meaning and use of evidentials in Modern Georgian]. Kartuli enis st'rukt'uris sak'itxebi 4, 53-70.

Pietrandrea, Paola. 2005. Epistemic Modality. Functional Properties and the Italian System. Amsterdam-Philadelphia, John Benjamins Publishing Company. 
Pkhakadze, Darejan. 1984. P'irveli turmeobitis punkciebi kartulši [Functions of the $1^{\text {st }}$ evidential (present perfect) in Georgian]. Tbilisi: Tbilisis universit'et'is gamomcemloba.

Sakhokia, Maia. 2002. New analytical perfects in Modern Georgian. Proceedings of the 3rd and $4^{\text {th }}$ International Tbilisi Symposium on Language, Logic and Computation, ILLC/ICLC, ed. by H. Zeevat D. de Jongh and M. Nilsenova. Amsterdam/Tbilisi,1-10.

Shabashvili, Giuli. 2001. P'erpekt'isa da unaxaobis k'at'egoria dzvel kartulši [The Category of perfect and non-witnessedness in Old Georgian], Doctoral Dissertation, University of Tbilisi.

Shanidze, Akaki. 1930. Kartuli gramat'ik'a, I. Morpologia [Georgian Grammar, I. Morphology], Tbilisi.

-----. 1953. Kartuli enis gramat'ik'is sapudzvlebi [Foundations of Georgian Grammar]. Tbilisi

-----. 1973. (Reprint 1980). Kartuli enis gramat'ik'is sapudzvlebi [Foundations of Georgian Grammar]. Tbilisi: Sakartvelos ssr mecnierebata ak'ademia.

Sharashenidze, Nino. 1995. Unda modaluri pormis ist'oriisa da morposint'aksuri analizisatvis [On the History and Morphosyntactic Analysis of the Modal Form unda] Enatmecnierebis sak'itxebi, 1999/4, Tbilisi, 49-56.

Topadze, Manana. 2008. Mezzi di espressione dell'evidenzialità in Georgiano. Pavia: Università degli Studi di Pavia (Doctoral Dissertation).

Willett, Thomas (1988) "A Cross-Linguistic Survey of the Grammaticization of Evidentiality", Studies in Language 12, (1988: 51-97).

Wiemer, Björn. 2008. Pokazateli s citativnoj i inferentivnoj funkcijami v russkom i pol'skom

jazykach - kommunikativnye mechanizmy semantičeskogo sdviga [Indicators with reportive and inferential functions in Russian and Polish languages - Communicative mechanisms of the semantic shift]. In: Lexikalische Evidenzialitätsmarker im Slavischen (=Wiener Slawistischer Almanach, Sonderband 72), ed. by Björn Wiemer and Vladimir A. Plungjan, 337-378.

-----. 2008a. Lexikalische Markierungen evidenzieller Funktionen: zur Theoriebildung und empirischen Erforschung im Slavischen. In: Lexikalische Evidenzialitätsmarker im Slavischen (=Wiener Slawistischer Almanach, Sonderband 72), ed. by Björn Wiemer and Vladimir A. Plungjan, 5-50.

-----. 2010. Hearsay in European languages: toward an integrative account of grammatical and lexical marking. In: Linguistic Realization of Evidentiality in European Languages (Empirical Approaches to Language Typology [EALT]), volume 49. ed. by Gabriele Diewald \& Elena Smirnova. Berlin, New York, Mouton de Gruyter, 59-130.

Author's Contact Information:

Manana Topadze Gäumann

Università di Pavia

topadze@gmx.ch 